
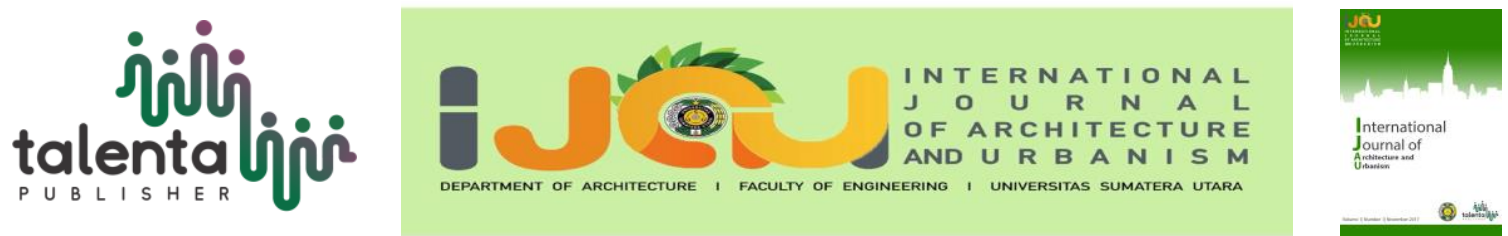

\title{
Public Hospital Type C Pekan Labuhan
}

\author{
Audina Muhvira ${ }^{1 *}$, Nelson M. Siahaan ${ }^{1}$ \\ ${ }^{1}$ Department of Architecture, Universitas Sumatera Utara, Medan, Indonesia
}

\begin{abstract}
The rapid economic growth in Medan Labuhandistrict has an impact on improving living standards and population growth. This is also in line with the availability of public facilities and infrastructure because the higher the level of one's life, the higher the quality of facilities. Furthermore it is needed a container to full fill the need for medical services both medical and non medical are realized through the design of "Public Hospital Type C Pekan Labuhan" with the aim as a container that provides health services and conduct activities related to health and supported by the facilities within it to achieve that goal. Public Hospital Type C Pekan Labuhan is designed by applying neo vernacular architectural themes so that it can align this building in surrounding buildings and able to support the existence of heritage conservation area activities in this region. Public Hospital Pekan Labuhan as one of the hospitals certified Class C Hospital is expected to function by the Regulation of the Minister of Health of the Republic of Indonesia.
\end{abstract}

Keyword: neo-vernacular, design, public, hospital.

\section{Introduction}

Healthy is the biggest investment that is very important for a nation. Not only as a human right, but also an obligation for every citizen by is stipulated in the Law of the Republic of Indonesia number 23 of 1992 Chapter 1, Article 1, point 4, which reads: "Health advice is the place used to conduct health efforts."

The hospital is an organization with an organized medical professional as well as a permanent medical facility in administering medical services, continuous nursing care, diagnosis, and treatment suffered by patients [1]. Medan Labuhan district is one of the areas that began to develop. This resulted in a relatively high population growth which will affect the people's living needs for adequate facilities and facilities, one of the needs for health facilities. Health facilities for Medan Labuhan area are still very limited. This can be seen from the at least health facilities available in this area, especially in Pekan Labuhan village.

*Corresponding author at:Department of Architecture, Faculty of Engineering, Universitas Sumatera Utara, Jalan Perpustakaan Gedung J07, Medan 20155, Indonesia

E-mail address: audina.muhvira31@gmail.com 


\section{Literature Review}

The design of public hospital Pekan Labuhan is designing Public Hospital Type C which includes architectural design, structural design, circulation design, utility design, and development master plan based on function, shape, user activity, and related government regulation. This discussion is based on analyzes derived from literature studies and comparative studies.

In the modern era today there are many new technologies that are endless, not least in the field of architecture. This technology is not only about the new material but also about how to build, the purpose of building so that over time the original architecture of an area abandoned for various reasons. There are some views that traditional buildings are outdated or out of date. Along with the development of science knowledge and various paradigms then in some existing references, the vernacular term is more for the contentrelationship with locality [2].

Neo-Vernacular architecture grows from the customs of society and progresses through the configuration stage stages of various cultures so that it has external power. In the other hand, the community already has a strong regional cultural tradition that has been recognized by the community for decades. In this case, the location of the design surrounded by historic areas that will be preserved sustainability. To conserve the heritage area then the architecture adopted is the colonial architecture.

\section{Methodology}

The design of research used in the design of Public Hospital Type C Pekan Labuhan is a qualitative research method, the research method used to examine the condition of natural objects as opposed to the experiment. Qualitative research is a study for understanding social reality, that is seeing the world from what it is, not the world that should be, then a qualitative researcher must be people who have the nature of open-minded In this quantitative research there are several methods that carried out short of field survey, participant observation, literature studies and case studies.

The design site selection reference based on the Building and Environmental Management Plan of Chinatown Medan Labuhan Area. Based on the Plan of Building and Environment, the designing location is intended for several functions, namely services and trade, transportation services, and health services.

\section{Result and Discussion}

Location of Public Hospital Pekan Labuhan is in District of Medan-Labuhan. Medan-Labuhan Sub-district is one of the districts located in Medan City which has an area of about $36.67 \mathrm{~km}^{2}$ or $13.83 \%$ of the total area of Medan. The location of the design is on the road Yos Sudarso, 
Kecamatan Medan Labuhan, Kelurahan Pekan Labuhan, which has a land area of $20.000 \mathrm{~m}^{2}$ (Figure 1).

Precisely in Chinatown area which is a heritage area. This area according to the base of space territory system in Medan City is the center of services and trade, transportation services, and health services. The land in this project is a residential area of $2 \mathrm{Ha}$ land with the land use as the center of health service activities. The primary arterial road is 26 meters, has KDH $15-40 \%$ and KDB $60-80 \%$.

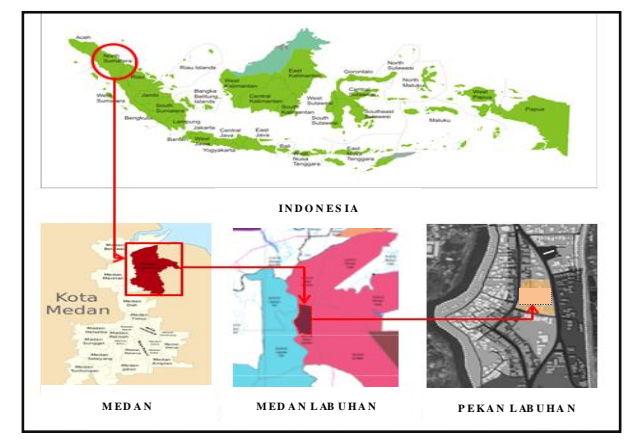

Figure 1. Map of the existing location

(Source: http://www.google.earth.com)

Conditions at the current design site consist of vacant land, and residents' homes. The location area is located on the edge of the main road Yos Sudarso and is in the middle of the settlement with a time of one hour from Medan city center using public transportation or private vehicle. The location is close to the railway station. Medan Labuhan. The location is also close to the port of Belawan with a travel time of 15 minutes using a private vehicle.

Chinatown area the area designated as the allocation of social facilities and public facilities of the planning area in the analysis of land use, the circumstances surrounding the location surrounded the settlement of citizens and there is also an old market called by residents with crooked old markets, there are some schools and also places of worship. Hospitals must plan with the proper grouping of space will support the effectiveness and efficiency of activities that take place within and between spaces. Appropriate grouping will also give the proximity of space that requires each other, and to separate the space that binds the separator.

The outer zone is a zone that should be easily accessible to the wider community, such as emergency service placement, outpatient services, and general administrative services. The second zone is the zone that receives the workload from the outer zone including laboratory, pharmacy, and radiology. The deepest zone is a zone that requires a certain level of stability that provides, services, such as surgical services, childbirth, and intensive care. Last is the service zone, which provides services on hospital activities, such as kitchens, laundry, IPRS, vehicle pools, and mortuary [3]. 
The analysis of implementation theme on the design Public Hospital Pekan Labuhan is more to adjust to the existing in the local area as well as the implementation of the utility system, which is a form of contribution to environmental conservation. Adjustment of the facade to the local building that is with colonial facade by Chinatown area where there is a heritage area that located very close to the location of the project. As is known, the colonial architecture is very sensitive in responding to the direction of the sun, for it follows a solution that will be applied to the design of Public Hospital Pekan Labuhan by applying a double skin face system to respond to the eastern and western sides, applying landscape design by the needs of space open green, natural daylight sourced from sunlight, applying environmentally friendly material to the inner chamber thereby, creating the thermal comfort needed by building users.

There are 7 aspects that must be considered to make a concept of physical and non-physical development planning an area that has cultural and historical value, 7 aspects are: Land Use And Tenure, Land Use Regulation, Property Value, Public Infrastructure, Building And Neighborhood Character, Historic Resources, and Sensory Perception [4]. An important feature of both Vernacular and Neo-Vernacular architecture is the ecologically responsive value of the environment and always refers to local potential, capability and skills, practical knowledge and traditional techniques. Neo-Vernacular architecture has agreements that respond positively to climate. This architecture also provides the principles and symbols of the past to be transformed into a new form that will be beneficial to the changing changes in the present social order.

The colonial architecture is very sensitive to the tropical climate. The colonial architecture looks very well with the ventilation and daylighting of nature in a mixture of early European and traditional European architecture. Colonial architecture has implemented a passive system by relying on natural conditions in humid tropics. One of the dominant problems in the humid tropics is the amount of solar radiation that affects the condition of the inner chamber of the building. In this case, the role of structures and roof of the building becomes important to handle the education of solar radiation (Figure 2).

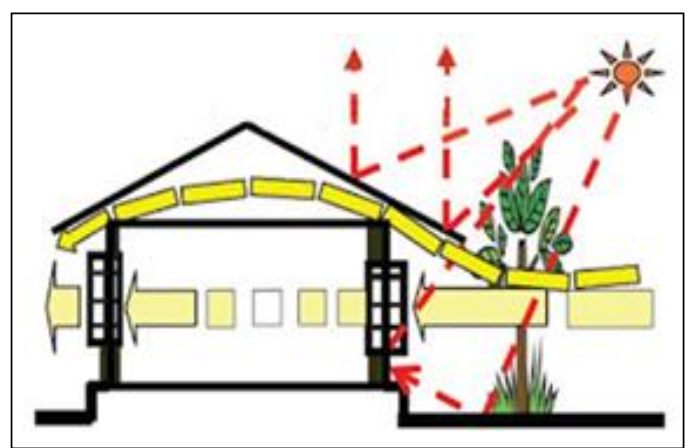

Figure 2. Natural Light and Air Application

Location of design with an area of $\pm 20,000 \mathrm{~m}^{2}$ located on Yos Sudarso Medan Labuhan has a building border line of seven meters from the main road. There are three zoning in the building 
that is a mass of the main building, mechanical building with the base coefficient of building $60 \%-80 \%$ or $\pm 16.000 \mathrm{~m} 2$ and open space $15 \%-40 \%$ from land or $\pm 4,000 \mathrm{~m} 2$ (Figure 3 ).

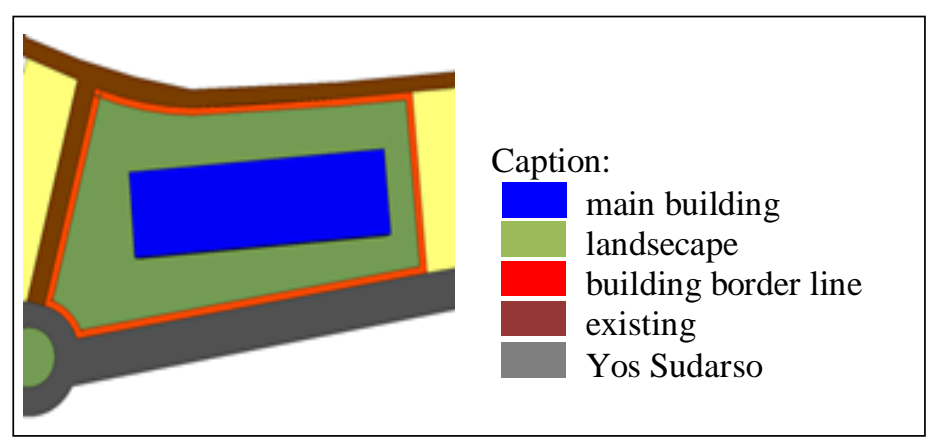

Figure 3. Zoning Of Site

Outside spatial arrangement on the site-oriented on the tread processing around the main mass which functioned as parking area and park. The parking area arranged on all four sides of the building. This is because the hospital parking needs to serve certain functions. At the entrance there are parks, drop off areas, fountain, and circulation in and out of vehicles (Figure 4).

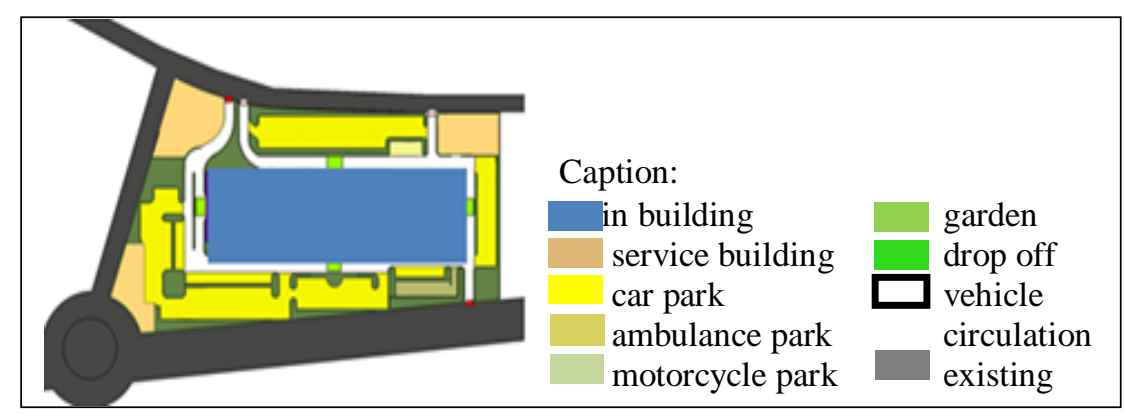

Figure 4. Outdoor Space Zoning

The mass of the building overlooks the main street of Yos Sudarso. Therefore the building faces east. Buildings that have an eastward direction get more sunlight in the morning which is certainly good for health. But the heat of the sun is needed in a building, but should not be excessive. This will reduce the comfort in the building (Figure 5).

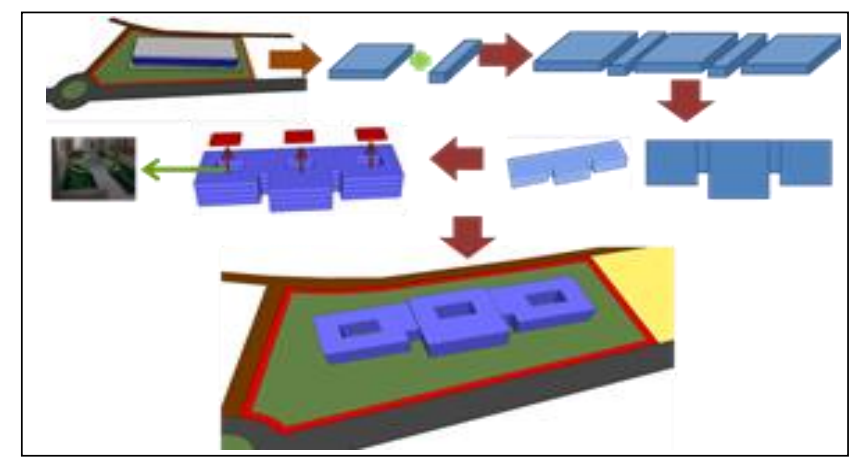

Figure 5. Mass composition 
However, sunlight is needed to help save electricity use during the day in the building. Direction to face the house can actually to handle by processing the right form of the building. Suppose the building is rectangular, orientation to the sun is more decisive when compared with square buildings. Then mass on the building of Pekan Labuhan General Hospital designed square length to get comfort for its users.

In the design of the site, there are three entrance vehicles but has an exit. To enter the main entrance is on the way Syahbudin Yatim. That is adjacent to the exit of the vehicle. On the same road but the opposite side there is a special entrance for service. And on the street Yos Sudarso, there is an ambulance entrance. The ambulance path is made on Yos Sudarso road to make it easier for emergency patients who need quick handling.

Planning design of the parking area by the concept of circulation that surrounds the building. This is because the parking needs of a hospital that must serve certain functions, such as a hearse, ambulance bay and staff should have their parking area. This is related to the ease of access and separation between private and public channels (Figure 6)

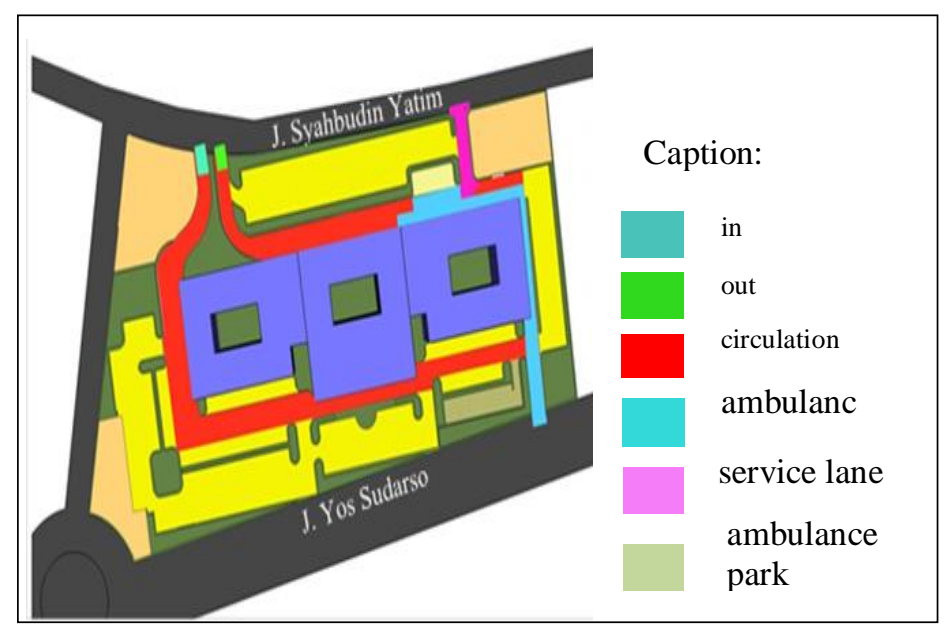

Figure 6. Circulation of Achievement

The hierarchy of space on the design site begins with Syahbudin Yatim road is the main entrance to the designing tread. The separator between the public spaces and the designing treads handled by the fence boundary design concept, so it is clear the physical boundary between the public space and the design site.

Public Hospital Pekan Labuhan there is 3 zone section that is service area, supporting area, and administration and management. The service areas include outpatient installations, emergency room installations, inpatient installations, intensive care installations, surgical installations, medicinal and obstetric diseases, medical rehab installations and radiological installations. Supporting and operational areas divided into two parts: medical and nonmedical supporters. 
Medical support consists of pharmaceutical chambers, radiodiagnostic chambers, laboratories and body mazes. Non-medical support consists of sterilization center, kitchen/ nutrition, laundry, sanitation room and maintenance room. The administrative and management area is part of the hospital management office.

Zoning of Public Hospital Pekan Labuhan there are four parts of the outer zone, the second zone, the deepest zone, and the service zone. Outermost zones such as emergency service deployments, outpatient services, and general administration. The Second zone such as laboratory, pharmacy, and radiology. And the deepest zone is like surgical service, childbirth, and intensive care. Service zones such as kitchen, laundry, and mortuary.

Public Hospital Pekan Labuhan uses two types of circulation, namely horizontal circulation in the form of corridors and vertical in the form of stairs and elevators. In some areas, the service has a requirement that the circulation flow must close from the public sphere, such as the circulation of the corpse either from the corpse or other space.

The structural system used in the design of a public hospital at harbor week is the rigid frame system, where the structure focuses more on the grid system that supports the function of the spaces within it. The combination of cores and columns to form a structure that can support the load that is above it. And also use the structure, in general, such as; sloof, column, beam, beam ring and dilation. The main building column uses a $60 \mathrm{~cm}$ x $60 \mathrm{~cm}$ column. This building uses boor pile foundation (Figure 7).

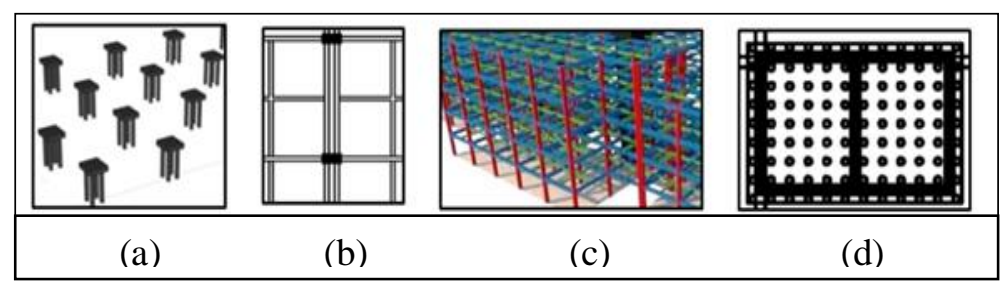

Figure 7. (a) Tiang Pancang, (b) Dilatation, (c) Grid, (d) Core.

\section{Conclusion}

Public Hospital Pekan Labuhan is located in a very potential location to be developed into a metropolitan area because the site location is very close to the port and is also a development area as a facility that must realize in the area. Public Hospital Pekan Labuhan designed with the classification of $\mathrm{C}$ with the number of floors four and five floors. Public Hospital Pekan Labuhan is designed on site with planned road plans into the arterial road so that the intensity of activity in the hospital will increase.

The building is themed Neo Vernacular Architecture, a built environment in which local forms of reference drawn by taking existing architectural elements into modern forms with the aim of preserving the local elements that have been empirically established by a tradition without 
overriding the values of local tradition. In this case, Public Hospital Type C Pekan Labuhan took the theme of colonial architecture on the concept of its application.

\section{Acknowledgment}

This research is part of the requirement to obtain a bachelor's degree in Architecture Departement Universitas Sumatera Utara.

\section{REFERENCES}

[1] A. F. Handbook. American society of heating, refrigerating and air-conditioning engineers. Inc.: Atlanta, GA, USA, 2009.

[2] I. Mentayani and A. Ikaputra. Menggali Makna Arsitektur Vernakular: Ranah, Unsur, dan Aspek-Aspek Vernakularitas. LANTING Journal of Architecture, 1(2), 68-82, 2012.

[3] A. U. Hatmoko. Arsitektur Rumah Sakit. PT. Global Rancang Selaras, 2011.

[4] J. A. LaGro Jr. Site analysis: A contextual approach to sustainable land planning and site design. John Wiley \& Sons, 2011. 